\title{
Diagnostic value of inflammatory markers in chronic respiratory disease of the horse - a review
}

\author{
Ann Kristin Barton, Tarek Shety, Caroline Wirth and Heidrun Gehlen \\ Klinik für Pferde, Allgemeine Chirurgie und Radiologie der Freien Universität Berlin
}

\begin{abstract}
Summary: Over the last years local and systemic inflammatory markers of chronic pneumopathies have gained increasing interest in research, as the pathogenesis of Recurrent airway obstruction (RAO) and Inflammatory airway disease (IAD) remains not fully elucidated in several details. In human medicine, Asthma bronchiale and Chronic obstructive pulmonary disease (COPD) have been found to be influenced by systemic inflammatory processes and the other way around. Inflammation, coagulation and fibrinolysis as well as extracellular remodeling show close interactions. Cytology of bronchoalveolar lavage fluid and tracheal wash is commonly used to evaluate the severity of local inflammation in the lung. Interleukins involved in the chemotaxis of neutrophils like Interleukin 8, 17 and 23 have been studied. Chronic obstructive pneumopathies lead to remodeling of bronchial walls and lung parenchyma, ultimately causing fibrosis. Matrix-metalloproteinases (MMPs) are discussed as the most important proteolytic enzymes during remodeling in human medicine. In the horse, MMP 9 seems to be a central player in chronic respiratory disease as well. A systemic involvement has been shown for RAO by increased acute-phaseproteins like serumamyloid $A$ and haptoglobin in peripheral blood during exacerbation. Studies focusing on these and further possible inflammatory markers for chronic respiratory disease in the horse are discussed in this review of literature.
\end{abstract}

Keywords: Inflammatory markers / horse / respiratory disease / recurrent airway obstruction / RAO /

\section{Diagnostischer Wert verschiedener Entzündungsmarker bei chronischen Atemwegserkrankungen des Pferdes - eine Übersich†}

In den letzten Jahren häufen sich Untersuchungen zu verschiedenen lokalen und systemischen Entzündungsmarkern bei chronischen Pneumopathien des Pferdes, da das Verständnis der Pathogenese von Recurrent airway obstruction (RAO) und Inflammatory airway disease (IAD) weiterhin nicht vollständig geklärt ist. Ein Blick in die Humanmedizin zeigt, dass das Asthma bronchiale und die Chronic obstructive pulmonary disease (COPD) durchaus in Zusammenhang stehen mit systemischen inflammatorischen Prozessen, so dass sich die lokalen Prozesse in der Lunge und systemische Entzündungsreaktionen gegenseitig beinflussen. Entzündung, Koagulation und Fibrinolyse sowie das extrazelluläre Remodelling sind eng miteinander verknüft. Zyłologische Untersuchungen der bronchoalveolären Lavageflüssigkeit und des Tracheobronchialsekrets stellen die gebräuchlichste Methode dar, den Schweregrad der lokalen Entzündung zu beurteilen. Hierbei ergeben sich Zusammenhänge zu Interleukinen, die an der Chemotaxis neutrophiler Granulozyten beteiligt sind, wie beispielsweise Interleukin 8, 17 und 23. Chronisch obstruktive Pneumopathien führen langfristig zu chronischen Umbauprozessen der Bronchienwände und des Lungenparenchyms (Remodelling), die mit der Bildung von Fibrosen einhergehen. Matrix-Metalloproteinasen (MMPs) gelten in der Humanmedizin als wichtigste proteolytische Enzyme bei diesem Remodelling und auch beim Pferd ergeben sich Zusammenhänge vor allem zur MMP 9. Verschiedene Akute-Phase-Proteine wie Serumamyloid A und Haptoglobin konnten während der Exazerbation einer RAO auch systemisch nachgewiesen werden. Studien zu diesen und weiteren möglichen Entzündungsmarkern für tiefe Atemwegserkrankungen des Pferdes sollen in der vorliegenden Arbeit vorgestellt und in Bezug auf ihren diagnostischen Wert diskutiert werden.

Schlüsselwörter: Entzündungsmarker / Pferd / Atemwegserkrankung / Chronisch obstruktive Bronchitis / COB

Correspondence: Dr. Ann Kristin Barton, Freie Universität Berlin, Klinik für Pferde, Allgemeine Chirurgie und Radiologie, Oertzenweg 19b, 14163 Berlin, Email: Ann-Kristin.Barton@fu.berlin.de

Citation: Barton A. K., Shety T., Wirth C., Gehlen H. (2014) Diagnostic value of inflammatory markers in chronic respiratory disease of the horse - a review. Pferdeheilkunde 30, 432-443

\section{Introduction}

Disorders of the respiratory system, particularly the lower airways, are the most frequently diagnosed conditions in sport horses evaluated for poor performance (Allen et al. 2006, Martin et al. 2000). Inflammatory airway disease (IAD) and exercise-induced pulmonary haemorrhage (EIPH) are two common problems affecting the lower airways of racehorses (Wood et al. 2005, Pascoe et al. 1981, Raphel and Soma 1982, Newton and Wood 2002). IAD and EIPH also play a role in warmbloods, nevertheless, the most common lower airway disease in these horses is Recurrent airway obstruction (RAO). The estimated prevalence in the northern hemisphere is about 10-20\% (Hotchkiss et al. 2007) with incidence and severity of the disease increasing with age and stabling, so that RAO is a common reason for the career's end in the performance horse (Deegen 1986, Lekeux and Duvivier 2004).
Since bronchoalveolar lavage (BAL) using fibre-optic endoscopy was first described in horses (Viel 1980), cytological and microbiological evaluation of tracheal washes (TW) and BAL fluid (BALF) have become the cornerstones in the diagnosis of respiratory disease alongside clinical and functional examinations. Although RAO patients in exacerbation often show easily visible signs of disease, difficulties may arise in clinical practice due to the fact that most patients are presented in remission. IAD tends to occur subclinically as well (Couëtil et al. 2007). Nevertheless, IAD may progress into RAO.

In these cases commonly used examination techniques may be insufficient for diagnosis and evaluation of treatment success. Therefore, multiple studies have been performed to establish further inflammatory markers for equine respiratory disease. Evidence exists that systemic involvement may exist in RAO as 
has been shown for human Asthma bronchiale (Bjermer 2007) and Chronic obstructive pulmonary disease (COPD, Rosenberg und Kalha 2012, Koutsokera et al. 2012). Therefore, not only markers for pulmonary inflammation dominated by neutrophils, but also systemic markers in peripheral blood may be rewarding in the evaluation of equine disease.

\section{Local inflammatory markers in TW and BALF}

Neutrophilia in TW and BALF is a predominant cytologic feature of inflammation in IAD and in particular in RAO (Derksen et al. 1995, Schusser et al. 1999, Fairbarn et al.1993, Tremblay et al. 1993), in which neutrophils migrate within hours into the airway lumen, followed by a late phase of migration. The collegial scientific Havemeyer Foundation Workshop (Robinson 2003) suggested that BALF collected from clinically healthy horses should contain about $60 \%$ macrophages, 35\% lymphocytes, $<5 \%$ neutrophils, $<2 \%$ mast cells, $<0.1 \%$ eosinophils, and occasional or no epithelial cells. In RAO Exacerbation horses present with dyspnea at rest, as shown by a maximum interpleural pressure $>15 \mathrm{~cm} \mathrm{H}_{2} \mathrm{O}$ caused by bronchoconstriction, mucosal swelling and mucus accumulation (Pirie 2014), and inflammation of the small airways, in which neutrophils exceed $25 \%$ in BALF cytology (Robinson 2001). The definitive diagnosis of IAD is also based on BALF cytology (Covëtil et al. 2007), which is characterized by an increase in the total nucleated cell count with mild neutrophilia (Fogarty und Buckley 1991, Moore et al. 1995, Couëtil und Denicola 1999, Holcombe et al. 2001) or lymphocytosis (Moore et al. 1995, Covëtil et al. 2001, Sánchez et al. 2005), or, alternatively, by increased mast cell (Hare et al. 1994, Hoffman et al. 1998) or eosinophil counts (Hare und Viel 1998). The disease is differentiated from RAO by missing dyspnea at rest (Robinson 2003) and a missing response on provocation with mouldy hay (Dixon et al. 1995). Apart from this provocation it is difficult to distinguish between $I A D$ and $R A O$ in remission using common clinical diagnostics.

The immunologic background of RAO remains not fully elucidated despite many studies on the pathogenesis (Lindberg et al. 2002, Ainsworth et al. 2003, Ainsworth et al. 2002, Gerber et al. 2003) and the therapeutic approach to exacerbation (Jackson et al. 2000, Robinson et al. 2000a und 2000b, Rush et al. 2000, Henrikson und Rush 2001, Leguillette et al. 2002, Lavoie et al. 2002, Robinson et al. 2002a und 2002b, Picandet et al. 2003, Mazan et al. 2003, Rikkards et al. 2003, Robinson et al. 2003). Althouh evidence for a Th-2 based hypersensitivity reaction of allergy type-IV tends to overwhelm (Lavoie et al. 2001, Beadle et al. 2002, Cordeau et al. 2004), there is also evidence for a Th- 1 based immunologic background of the disease. Increased levels of Interleukin 4 and 5 as well as decreased Interferon- $\gamma$ expression support a Th-2 base (Cordeav et al. 2004). Lavoie et al. (2001) showed that recombinant equine IL-4 causes morphological changes in blood neutrophils, increases IL-8 mRNA levels and potentiates effects of LPS and TNF- $\alpha$ on IL- 8 expression by pulmonary artery endothelial cells. Receptors for IL-4, however, were not increased on neutrophils of RAOaffected compared to healthy horses, but a genetic linkage of polymorphisms in IL-4-receptor- $\alpha$ on chromosome 13 with $\mathrm{RAO}$ was found and increased expression of this receptor in one high-prevalence family of horses, but not in another one
(Gerber et al. 2008). On the other hand, Ainsworth et al. (2003) demonstrated increased interferon- $\gamma$ production in BAL cells, which supports a Th1-based background for RAO, while still others suggest no involvement of either type response in this disease (Kleiber et al. 2005). Inhalation of immune modulatory, specific bacterial DNA-sequences (CpG-nanoparticles) modified the profile of expressed cytokines in RAO patients towards a Th- 1 profile and was accompanied by a marked reduction in clinical signs and neutrophilia in TW (Klier et al. 2012).

IL-8 is the predominant chemokine for neutrophils and was shown to be increased in BALF within hours after changing roughage feed from gras silage to hay in RAO affected horses (Franchini et al. 2000). In chronic inflammation IL-17 (Debrue et al. 2005) and IL-1B and IL-23 also play a role (Ainsworth et al. 2007).

While the percentage of neutrophils in BALF decreases to reference levels in phases of remission, which hinders cytologic diagnosis of the disease, myeloperoxidase (MPO) concentration in BALF was significantly higher in RAO-affected horses during either crisis or remission compared to control horses (Art et al. 2006). Therefore, MPO may serve as a sensitive inflammatory marker in subclinical cases (Fey 2004). In unison to this, several studies demonstrated reduced anti-oxidative capacity in RAO patients in exacerbation as evidenced by low ascorbic acid concentrations in BALF (Deaton et al. 2004, 2005a, 2005b, 2006 a und 2006b). During recovery from exacerbation, the reduction in ascorbic acid is followed by an increase in BALF glutathione peroxidase activity, presumably to combat disease-associated oxidative stress (Deaton et al. 2006). Furthermore, markers of oxidative stress have been identified within the airways and in exhaled breath condensate of RAO horses during disease exacerbation, but not following short-term organic dust inhalation challenge (Deaton et al. 2005b und 2006b).

\section{Systemic inflammatory markers in the blood}

Pulmonary neutrophilic inflammation during exacerbation has been the focus of many studies. It is largely reversible by antigen withdrawl in a low-dust- environment (Robinson 2001). However, evidence exists that the inflammatory processes are not completely resolved as residual airway bronchoconstriction, elevated smooth muscle cell turnover surrounding the airways, and higher nuclear factor $\kappa \mathrm{B}(\mathrm{NF}-\kappa \mathrm{B})$ activity are observable in asymptomatic horses affected with RAO (Leclere et al. 2011, Miskovic et al. 2007, Sandersen et al. 2001). NF- B is a specific transcription factor that has a key role in inflammatory processes. During disease exacerbation, peripheral blood leucocyte activation and increased concentration of circulatory inflammatory mediators have been observed in affected horses, suggesting that the inflammatory process might not be limited to the lung (Lavoie-Lamoureux et al. 2010, Rickards et al. 2004, Marr et al. 2002, Kirschvink et al. 2002, Gray et al. 1989). Human asthma, which shares many pathophysiological features with equine RAO, is considered to be a systemic disease, as an increase in several inflammatory markers has been observed in the blood of affected patients (Bjermer 2007). These include immunity-related mediators (cytokines, eicosanoids, cyclooxygenase products and lgEs) and the acute 
phase markers C-reactive protein, haptoglobin, fibrinogen and serumamyloid A (Kasayama et al. 2009, Wu et al. 2007, Koh et al. 1996). Systemic inflammation in patients with chronic airway diseases is thought to contribute to comorbidities (Biermer 2007, Schanen et al. 2005, Song et al. 2010, Sin et al. 2006, Yende et al. 2006).

Literature on systemic inflammatory processes in equine RAO is rare. Lavoie-Lamoureux et al. (2012a) compared several acute phase proteins (haptoglobin, serumamyloid $A, C$-reactive protein) and cytokines (interleukin-2, -4 and -10 as well as interferon- $\alpha$ und $-\beta$ ) in serum of healthy individuals and RAO affected horses over 30 days of exposition to hay and straw. Haptoglobin was found to be a suitable marker for both acute and chronic systemic inflammation, whereas high concentrations of serumamyloid A indicated acute inflammation. There was no difference in serum concentrations of the evaluated cytokines between affected horses and controls. In another study though, increased TNF- $\alpha$ concentrations were found after ex vivo stimulation with bacterial products in RAO affected horses (Lavoie-Lamoureux et al. 2012b). Niedzwiedz et al. (2011) found increased markers for oxidative stress in peripheral blood during exacerbation compared to controls.

Since the 1970s a correlation of sepsis and hypocalcemia has gained increasing attention in research. In sepsis, procalcitonin (PCT) is found in high concentration in the peripheral blood and is expressed by many organ tissues (Müller et al. 2001). PCT is a precursor of the hormone calcitonin, which regulates calcium metabolism by inhibition of osteoclast activity. In healthy subjects, pre-procalcitonin (pre-PCT) is produced exclusively in the thyroid gland. PCT plasma concentrations in acute local inflammatory processes in the lung are much lower than in sepsis, but allow differentiation between pulmonary disease in men (Pareira et al. 2013, Julián-Jiménez et al. 2013, Berg und Lindhardt 2012). For example, PCT was used for differentiation of tuberculosis from other pneumopathies (Niv et al. 2013).

In chronic pulmonary disease like human asthma, increased PCT concentrations were found as well. Acute exacerbations are often accompanied by bacterial infections of the lower airways. PCT can be used in the decision for or against antibiotic treatment and may help to interpret diffuse thoracic radiographs (Tang et al. 2013, Walsh et al. 2013). In COPD, PCT eases the decision for antibiotics or glukocorticoids (Brightling 2013). It is also useful for follow up in COPD (Zhao et al. 2013). Rieger et al. (2014, accepted) established an ELISA for equine PCT. Clear differences were found between septic horses and healthy individuals. PCT may also be a suitable marker for chronic pneumopathies in the horse.

\section{Coagulation and fibrinolysis}

In the long term, chronic obstructive pneumopathies lead to chronic remodeling of bronchial walls and lung parenchyma, which is accompanied by fibrosis formation (Kaup et al. 1990a, 1990b, Lavoie et al. 2005, Ainsworth 2010). This remodeling is favoured by procoagulatory conditions, while fibrinolysis serves to remove alveolar fibrin deposits and counteracts coagulation and beginning fibrosis (Seeger et al. 1985).
After mechanical and inflammatory defects, which destroy the capillary endothelium and in particular the alveolar epithelium, plasma proteins transudate into the alveolar space and activate coagulation, of which fibrin is the end product. This is part of the natural healing and repair process and serves as a primary occlusion of the membranous defect (Günther et al. 2000). On the other hand, excessive and persistant coagulation is pathologic and leads to fibrin deposition and fibrosis formation, which has a negative impact on pathogenesis and progression of multiple respiratory diseases (Nakstad et al. 1990, Akinnusi und El Solh 2007).

Apart from favoring fibrosis formation, fibrin and its derivates influence pathomechanisms of inflammation and the further course of the disease and repair of affected lung tissue (/dell 2003). Fibrin stimulates migration of inflammatory cells (Ciano et al. 1986, Leavell et al. 1996) as well as adhesion and proliferation of fibroblasts with following collagen production (Grinnell et al. 1980, Gray et al. 1995). The fibrin molecule modulates the inflammatory response by binding to monocy-

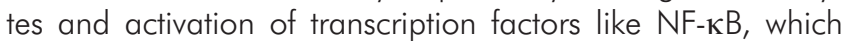
increases pro-inflammatory cytokine production (Sitrin et al. 1998). In addition, fibrin and its derivates inhibit surfactant, decreasing the alveolar surface tension, favoring micro atelectases and decreasing gas exchange. This dysfunction is caused by the inclusion of surfactant components into the fibrin matrix and a following dysfunction of the main phospholipid DPPC (Dipalmitoylphosphatidylcholin, Seeger et al. 1993). Interactions of surfactant with fibrinogen, fibrin monomers and other proteins have also been demonstrated; of these fibrin monomers have strongest inhibitory effect (Seeger et al. 1985).

It has been hypothesized early in human medicine that respiratory disease damaging the alveolar membrane must cause a dysbalance between coagulatory and fibrinolytic activity in the extravascular space. Studies on different parameters of fibrinolysis like U-PA (urokinase-type plasminogen activator), PAI-1 (pasminogen activator inhibitor 1), $\alpha 2-A P(\alpha 2$-antiplasmin) and on D-dimers have demonstrated an increase in coagulation in bronchoalveolar lavage fluid (BALF) in patients suffering from chronic respiratory disease (Günther et al. 2000). Coagulation and fibrinolysis have been shown to play an important role in the pathomechanisms of numerous pulmonary diseases in men, and the development of therapeutics supporting fibrinolysis is discussed as a promising approach (Ware et al. 2005).

In veterinary medicine and in particular in the equine lung, literature in this field is rare so far. Nevertheless, thickened alveolar interstitial spaces by the accumulation of fibrin and fibrinogen have been found in horses affected by chronic pulmonary disease (Winder et al. 1990). In severe cases, increased concentrations of fibrinogen derivates, proteases and procoagulatory activity could be demonstrated in respiratory secretions. The results of this study (Winder et al. 1990) allow the assumption that a dysbalance of extravascular homeostasis is also a feature of equine RAO, and that fibrin deposition, following fibrosis and surfactant dysfunction support the progression of the disease. Fibrinolysis has been studied in more detail in other organ systems, for example in plasma and peritoneal fluid of horses suffering from colic (Delgado et al. 2009, Monreal et al. 2000) and in synovial fluid of foals affected by arthritis (Ribera et al. 2011). 


\section{Extracellular remodelling}

Remodelling of the extracellular matrix (ECM) of pulmonary connective tissue is a continuous process allowing growth and regeneration. To maintain the tissue's stability, a balance between degradation, in which matrix metalloproteinases are the most important proteolytic enzymes, and re-synthesis of extracellular matrix structures is required (Clutterbuck et al. 2010). The pulmonary interstitium forms the mechanical scaffold of the lung, while the basement membrane supports alveolar epithelial cells and in part determines the resistance of the diffusion barrier (Dunsmore und Rannels 1996). The primary structural fibrils of the lung are composed of type I collagen and elastin. Elastin fibres are very elastic and stable for a long time (Shapiro et al. 1991a). The alveolar wall is primarily composed of type III collagen (Foronjy et al. 2003), while the basement membrane is rich in type IV collagen. Large collagen and elastin fibres are connected by a variety of smaller fibrils. Degradation of the primary structural fibrils of the lung will therefore involve cleavage of the cross linking fibrils to expose enzyme binding sites (Shapiro et al. 1991b). Multiple enzymes are involved in the turnover of the ECM and it may be impossible to specify a single protease as the critical mediator of any particular pulmonary disease.

The function of matrix metalloproteinases (MMPs) has originally been described over fifty years ago (Gross and Lapiere 1962). MMPs play an important role in the turnover of the extracellular matrix (ECM) components, tissue degradation, repair mechanisms and cell migration (Ratjen et al. 2002). Their best known physiological function is the cleavage and rebuilding of connective tissues (Krizkova et al. 2011). MMPs may play a crucial role in inflammatory reactions by regulating physiologic barriers, modulation of cytokines and chemokines, establishing a chemokine gradient to regulate the leukocyte accumulation into the inflamed tissue (Naito and Yoshikawa 2005).

MMPs are very likely to have a central role in destructive pulmonary disease, as type I collagen is very resistant against enzymatic degradation, which is possible only by few specific MMPs at physiologic pH (Brinckerhoff and Matrisian 2002). Some MMPs are elastases that may also degrade type IV collagen (Parks et al. 2004). Several studies have demonstrated a central role of MMPs in chronic respiratory disease in men and horses. MMPs are assumed to be as the major proteolytic enzymes involved in the pathogenesis of COPD (Atkinson et al. 2011 , Russell et al. 2002). Increased levels of MMP-1 and MMP-9 have been detected in BALF of patients with emphysema (Finlay et al. 1997a), which are produced by macrophages (Finlay et al. 1997b).

Several studies have been performed in horses, in which MMPs were evaluated by zymography in BALF samples. In moderate to severe RAO increased MMP-2 and MMP-9 concentrations were found compared to healthy controls (Koivunen et al. 1997a). In particular MMP-9 seems to play a pathophysiologic role (Barton et al. 2013). Both MMP-2 and MMP-9 showed a correlation to stable dust concentrations that contains fungal moulds and endotoxins (Nevalainen et al. 2002, Simonen-Jokinen et al. 2005a und 2005b). MMP9 also correlated to BALF neutrophilia and decreased with neutrophilia after therapy (Barton et al. 2013). This was not found for MMP-2, which seems to have a constitutive role in physiologic tissue remodeling (Koivunen et al. 1997a). Raulo et al. (2001a) were also unable to demonstrate increased MMP-2 and MMP- 14 activity in TW and BALF in RAO, but up to 7-times increased activity of MMP-9, MMP-8 and MMP-13, produced by pulmonary macrophages and epithelial cells (Raulo et al. $2001 \mathrm{a}$ and $2001 \mathrm{~b}$ ).

It seems desirable to develop therapeutic approaches that protect the lung against overwhelming MMP activity but allow physiologic cell remodelling, which is important in the immunology of healing processes (Elkington und Friedland 2006). To prevent uncontrolled turnover of the ECM, inflammation, cellular growth and migration, MMP activity must be tightly controlled on the levels of transcription, zymogen activity and by endogenous inhibitors. Overwhelming MMP acitivity in the horse could be inhibited in vitro with doxycycline (Koivunen et al. 1997b).

Tissue inhibitors of metalloproteinases (TIMPs) are natural, endogenous MMP-inhibitors that regulate MMP-induced turnover of the ECM, tissue remodeling and cellular behaviour (Bourboulia und Stetler-Stevenson 2010, Brew und Nagase 2010). Next to several MMPs, TIMP-1 and TIMP-2 were found to be increased in tuberculosis in men (Ugarte-Gil et al. 2013) and decreased after successful therapy. In COPD, local MMP-9 and TIMP-1 concentrations in BALF were high, while they were low in plasma (D'Armiento et al. 2013). In interstitial pneumopathies MMP and TIMP patterns have been discussed as possible prognostic markers and TIMP inhalation as a possible therapeutic approach (Oka et al. 2013). There are some synthetic inhibitors that regulate the pathologic effects of MMPs and might support the healing process of epithelial membranes in the airways (Bourboulia und StetlerStevenson 2010, Brew and Nagase 2010).

\section{Conclusions}

In conclusion, the results of the studies reviewed here show the complexity in the pathogenesis of respiratory disease in the horse. Therefore, it is a challenge to find new therapeutic approaches to these pathologies with high economic impact. Nevertheless, the numerous inflammatory markers that have been established for horses so far may help to understand the pathogenesis of lower airway disease in more detail and to diagnose the different diseases correctly even in subclinical cases. Further studies should focus on the course of the evaluated markers during therapy to evaluate their use in followup after therapy or during long-term-therapy and to evaluate the success of established, but also of new therapeutic approaches for chronic respiratory disease.

\section{References}

Ainsworth D. M. (2010) Review of Recurrent Airway Obstruction (RAO, Heaves): Diagnosis and Treatment Options. Proceedings of the AAEP Focus on Upper and Lower Respiratory Diseases - Salt Lake City, UT, USA

Ainsworth D. M., Wagner B., Erb H. N., Young J. C., Retallick D. E. (2007) Effects of in vitro exposure to hay dust on expression of interleukin-17,-23,-8, and -1 beta and chemokine (C-X-C motif) ligand 2 by pulmonary mononuclear cells isolated from horses chronically affected with recurrent airway disease. Am. J. Vet. Res. $68,1361-1369$ 
Ainsworth D. M., Wagner B., Franchini M., Grünig G., Erb H. N., Tan J. Y. (2006) Time-dependent alterations in gene expression of interleukin-8 in the bronchial epithelium of horses with recurrent airway obstruction. Am. J. Vet. Res. 67, 669-677

Ainsworth D. M., Grünig G., Matychak M. B., Young J., Wagner B., Hollis N. E., Antczak D. F. (2003) Recurrent airway obstruction (RAO) in horses is characterized by IFN- and IL-8 production in bronchoalveolar lavage cells. Vet. Immunol. Immunopathol. 96, 83-91

Ainsworth D. M., Appleton J. A., Antczak D. F., Santiago M. A., Aviza $G$. (2002) lgG antibody responses to an inhaled antigen in horses with "heaves" (recurrent airway obstruction). Vet. Immunol. Immunopathol. 84, 169-180

Akinnusi M. E., El Solh A. A. (2007) The role of coagulation in pulmonary pathology. Inflam. allerg. targ. 6, 201-209

Allen K. J., Tremaine W. H., Franklin S. H. (2006) Prevalence of inflammatory airway disease in National Hunt horses referred for investigation of poor athletic performance. Equine Vet. J. 36, 529534

Art T., Franck T., Lekeux P., de Moffarts B., Couetil L., Becker M., Kohnen S., Deby-Dupont G., Serteyn D. (2006) Myeloperoxidase concentration in bronchoalveolar lavage fluid from healthy horses and those with recurrent airway obstruction. Can. J. Vet. Res. 70, 291-296

Atkinson J. J., Lutey B. A., Suzuki Y., Toennies H. M., Kelley D. G. (2011) The role of matrix metalloproteinase-9 in cigarette smokeinduced emphysema. Am. J. Resp. Crit. Care Med. 183, 876-884

Barton A., Shety T., Bondzio A., Einspanier R., Gehlen H. (2013) Changes in MMP-2, MMP-9 and IL-8 in BALF of RAO horses before and after therapy. Congress of the European College of Equine Internal Medicine, Le Touquet, Frankreich.

Berg .P, Lindhardt B. Ø. (2012) The role of procalcitonin in adult patients with community-acquired pneumonia--a systematic review. Dan. Med. J. 59, A4357.

Beadle R. E., Horohov D. W., Gaunt S. D. (2002) Interleukin-4 and interferon-gamma gene expression in summer pasture-associated obstructive pulmonary disease affected horses. Equine Vet. J. 34, 389-394

Bjermer L. (2007) Time for a paradigm shift in asthma treatment: From relieving bronchospasm to controlling systemic inflammation. Allerg. Clini. Immunol. 120, 1269-1275

Bourboulia D., Stetler-Stevenson W. G. (2010) Matrix metalloproteinases (MMPs) and tissue inhibitors of metalloproteinases (TIMPs): Positive and negative regulators in tumor cell adhesion. Seminars in Cancer Biology 20, 161-168

Brew K., Nagase H. (2010) The tissue inhibitors of metalloproteinases (TIMPs): an ancient family with structural and functional diversity. Biochim. Biophys. Acta 1803, 55-71

Brightling C. E. (2013) Biomarkers that Predict and Guide Therapy for Exacerbations of Chronic Obstructive Pulmonary Disease. Ann. Am. Thoracic Soc. 10 (Suppl), S214-219

Brinckerhoff C. E., Matrisian L. M. (2002) Matrix metalloproteinases: a tail of a frog that became a prince. Nature Reviews Molecular Cell Biol. 3, 207-14

Ciano P. S., Colvin R. B., Dvorak A. M., McDonagh J., Dvorak H. F. (1986) Macrophage migration in fibrin gel matrices. Laboratory Invest. 54, 62-70

Clutterbuck A. L., Harris P., Allaway D., Mobasheri A. (2010) Matrix metalloproteinases in inflammatory pathologies of the horse. Vet. J. 183, 27-38

Cordeau M.-E., Joubert P., Dewachi O., Hamid Q., Lavoie J. P. (2004) IL-4, IL-5 and IFN-gamma mRNA expression in pulmonary lymphocytes in equine heaves. Vet. Immunol. Immunopathol. 97, 87-96

Covëtil L. L., Denicola D. B. (1999) Blood gas, plasma lactate and bronchoalveolar lavage cytology analyses in racehorses with respiratory disease. Equine Vet. J. 30, 77-82

Covëtil L. L., Rosenthal F. S., DeNicola D. B., Chilcoat C. D. (2001) Clinical signs, evaluation of bronchoalveolar lavage fluid, and assessment of pulmonary function in horses with inflammatory respiratory disease. Am. J. Vet. Res. 62, 538-546
Couëtil L. L., Hoffman A. M., Hodgson J., Buechner-Maxwell V., Viel L., Wood J. L., Lavoie J. P. (2007) Inflammatory airway disease of horses. J. Vet. Int. Med. 21, 356-361

D'Armiento J. M., Goldklang M. P., Hardigan A. A., Geraghty P., Roth M. D., Connett J. E., Wise R. A., Sciurba F. C., Scharf S. M., Thankachen J., Islam M., Ghio A. J., Foroniy R. F. (2013) Increased matrix metalloproteinase (MMPs) levels do not predict disease severity or progression in emphysema. PLoS One 8, e56352

Deaton C. M., Marlin D.J ., Deaton L., Smith N. C., Harris P. A., Schroter R. C., Kelly F. J. (2006a) Comparison of the antioxidant status in tracheal and bronchoalveolar epithelial lining fluids in recurrent airway obstruction. Equine Vet. J. 38, 417-422

Deaton C. M. (2006b) The role of oxidative stress in an equine model of human asthma. Redox Rep. 11, 46-52

Deaton C. M., Marlin D. J., Smith N. C., Roberts C. A., Harris P. A., Schroter R. C., Kelly F. J. (2005a) Antioxidant and inflammatory responses of healthy horses and horses affected by recurrent airway obstruction to inhaled ozone. Equine Vet. J. 37, 243-249

Deaton C. M., Marlin D. J., Smith N. C., Harris P. A., Dagleish M. P., Schroter R. C., Kelly F. J. (2005b) Effect of acute airway inflammation on the pulmonary antioxidant status. Exp. Lung Res. 31, 653-670

Deaton C. M., Marlin D. J., Smith N. C., Harris P. A., Roberts C. A., Schroter R.C., Kelley F.J. (2004) Pulmonary epithelial lining fluid and plasma ascorbic acid concentrations in horses affected by recurrent airway obstruction. Am. J. Vet. Res. 65, 80-87

Debrue M., Hamilton E., Joubert P., Lajoie-Kadoch S., Lavoie J. P. (2005) Chronic exacerbation of equine heaves is associated with an increased expression of interleukin-17 mRNA in bronchoalveolar lavage cells. Vet. Immunol. Immunopathol. 105, 25-31

Deegen E. (1986) Das chronisch lungenkranke Pferd und sein Einsatz im Sport. Prakt. Tierarzt, Colleg Vet XVII, 15-19

Delgado M. A., Monreal L., Armengou L., Ríos J., Segura D. (2009) Peritoneal D-dimer concentration for assessing peritoneal fibrinoIytic activity in horses with colic. J. Vet. Int. Med. 23, 882-889

Derksen F. J., Scott J. S., Miller D. C., Slocombe R. F., Robinson N. E. (1985) Bronchoalveolar lavage in ponies with recurrent airwayobstruction (heaves). Am. Review. Resp. Dis. 132, 1066-1070

Dixon P. M., Railton D. I., McGorum B. C. (1995) Equine pulmonary disease: a case control study of 300 referred cases. Part 1: Examination techniques, diagnostic criteria and diagnoses. Equine Vet. J. $27,416-421$

Dunsmore S. E., Rannels D. E. (1996) Extracellular matrix biology in the lung. Am. J. Physiol. 270, 23-27

Elkington P. T., Friedland J. S. (2006) Matrix metalloproteinases in destructive pulmonary pathology. Thorax 61, 259-66

Fairbairn S. M., Page C. P., Lees P., Cunningham F. M. (1993) Early neutrophil but not eosinophil or platelet recruitment to the lungs of allergic horses following antigen exposure. Brit. Soc. Allergy . Clin. Immunol. 23, 821-828

Fey K. (2004) Der klinische Nutzen zytologischer Untersuchungen von broncho-alveolärer Lavageflüssigkeit bei der Differenzierung chronischer Bronchitiden des Pferdes. Habil. Med. Vet. Giessen

Finlay G. A., Russell K. J., McMahon K. J., D'arcy E. M., Masterson J. B., FitzGerald M. X., O'Connor C. M. (1997a) Elevated levels of matrix metalloproteinases in bronchoalveolar lavage fluid of emphysematous patients. Thorax 52, 502-6

Finlay G. A., O'Driscoll L. R., Russell K. J., D'Arcy E. M., Masterson J. B., FitzGerald M. X., O'Connor C. M. (1997b) Matrix metalloproteinase expression and production by alveolar macrophages in emphysema. Am. J. Resp. Crit. Care Medicine 156, 240-247

Fogarty U., Buckley T. (1991) Bronchoalveolar lavage findings in horses with exercise intolerance. Equine Vet. J. 23, 434-437

Foroniy R. F., Okada Y., Cole R., D'Armiento J. (2003) Progressive adult-onset emphysema in transgenic mice expressing human MMP- 1 in the lung. American Journal of Physiology - Lung Cellular and Molecular Physiology 284, 727-737

Franchini M., Gill U., von Fellenberg R., Bracher V. D. (2000) Interleukin-8 concentration and neutrophil chemotactic activity in bronchoalveolar lavage fluid of horses with chronic obstructive pulmonary disease following exposure to hay. Am. J. Vet. Res. 61, 1369-1374 
Gerber V., Swinburne J. E., Blott S. C., Nussbaumer P., Ramseyer A., Klukowska-Rötzler J., Dolf G., Marti E., Burger D., Leeb T. (2008) Genetics of recurrent airway obstruction (RAO). Deutsch. Tierärztl. Wschr. 115, 271-275

Gerber V., Robinson N. E., Venta R. J., Rawson J., Jefcoat A. M., Hotchkiss J. A. (2003) Mucin genes in horse airways: MUC5AC, but not MUC2, may play a role in recurrent airway obstruction. Equine Vet. J. 35, 252-257

Gray A. J., Bishop J. E., Reeves J. T., Mecham R. P., Laurent G. J. (1995) Partially degraded fibrin(ogen) stimulates fibroblast proliferation in vitro. Am. J. Resp. Cell Mol. Biol. 12, 684-690

Gray P. R., Derksen F. J., Robinson N. E., Carpenter-Deyo L. J., Johnson H. G., Roth R. A. (1989) The role of cyclooxygenase products in the acute airway obstruction andairway hyperreactivity of ponies with heaves. Am. Review. Resp. Dis. 140, 154-160

Grinnell F., Feld M., Minter D. (1980) Fibroblast adhesion to fibrinogen and fibrin substrata: requirement for cold-insoluble globulin (plasma fibronectin). Cell 19, 517-525

Gross J., Lapiere C. M. (1962) Collagenolytic activity in amphibian tissues: a tissue culture assay. Proc. Nat. Acad. Sci. USA 15, 48, 1014-22

Günther A., Mosavi P., Heinemann S., Ruppert C., Muth H., Markart P., Grimminger F., Walmrath D., Temmesfeld-Wollbrück B., Seeger W. (2000) Alveolar fibrin formation caused by enhanced procoagulant and depressed fibrinolytic capacities in severe pneumonia. Comparison with the acute respiratory distress syndrome. Am. J. Resp. Crit. Care Med. 161, 454-462

Hare J. E., Viel L. (1998) Pulmonary eosinophilia associated with increased airway responsiveness in young racing horses. J. .Vet. Int. Med. 12, 163-170

Hare J. E., Viel L., O'Byrne P. M., Conlon P. D. (1994) Effect of sodium cromoglycate on light racehorses with elevated metachromatic cell numbers on bronchoalveolar lavage and reduced exercise tolerance. Vet. Pharmacol. Therap. 17, 237-244

Henrikson S. L., Rush B. R. (2001) Efficacy of salmeterol xinafoate in horses with recurrent airway obstruction. J. Am. Vet. Med. Assoc. 218, 1961-1965

Hoffman A. M., Mazan M. R., Ellenberg S. (1998) Association between bronchoalveolar lavage cytologic features and airway reactivity in horses with a history of exercise intolerance. Am. J. Vet. Res. 59, 176-181

Holcombe S. J., Jackson C., Gerber V., Jefcoat A., Berney C., Eberhardt S., Robinson N. E. (2001) Stabling is associated with airway inflammation in young Arabian horses. Equine Vet. Jo. 33, 244-249

Hotchkiss J. W., Reid S. W., Christley R. M. (2007) A survey of horse owners in Great Britain regarding horses in their care. Part 2: Risk factors for recurrent airway obstruction. Equine Vet. J. 39, 301-8

Idell S. (2003) Coagulation, fibrinolysis, and fibrin deposition in acute lung injury. Criti. Care Med. 31 (Suppl), 213-20

Jackson C. A., Berney C., Jefcoat A. M., Robinson N. E. (2000) Environment and prednisone interactions in the treatment of recurrent airway obstruction (heaves). Equine Vet. J. 32, 432-438

Julián-Jiménez A., Timón Zapata J., Laserna Mendieta E. J., SiciliaBravo I., Palomo-de Los Reyes M. J., Cabezas-Martínez A., LaínTerés N., Estebaran-Martín J., Lozano-Ancín A., Cuena-Boy R. (2013) Diagnostic and prognostic power of biomarkers to improve the management of community acquired pneumonia in the emergency department. Enfermedades Infecciosas y Microbiología Clínica pii: S0213-005X(13)00132-8. doi: 10.1016/i.eimc.2013. 04.015

Kasayama S., Tanemura M., Koga M., Fujita K., Yamamoto H., Miyatake A. (2009) Asthma is an independent risk for elevation of plasma C-reactive protein levels. Clin. Chim. Acta 399, 79-82

Kaup F. J., Drommer W., Deegen E. (1990a) Ultrastructural findings in horses with chronic obstructive pulmonary-disease (COPD). 1. Alterations of the larger conducting airways. Equine Vet. J. 22, 343-348

Kaup F. J., Drommer W., Damsch S., Deegen E. (1990b) Ultrastructural findings in horses with chronic obstructive pulmonary disease (COPD) II: Pathomorphological changes of the terminal airways and the alveolar region. Equine Vet. J. 22, 349-355
Kirschvink N., Smith N., Fiévez L., Bougnet V., Art T., Degand G., Marlin D., Roberts C., Génicot B., Lindsey P., Lekeux P. (2002) Effect of chronic airway inflammation and exercise on pulmonary and systemic antioxidant status of healthy and heaves-affected horses. Equine Vet. J. 34, 563-571

Kleiber C., McGorum B. C., Horohov D. W., Pirie R. S., Zurbriggen A., Straub R. (2005) Cytokine profiles of peripheral blood and airway CD4 and CD8 T lymphocytes in horses with recurrent airway obstruction. Vet. Immunol. Immunopathol. 104, 91-97

Klier J., Fuchs S., May A., Schillinger U., Plank C., Winter G., Coester C., Gehlen H. (2012) A nebulized gelatin nanoparticle-based $\mathrm{CpG}$ formulation is effective in immunotherapy of allergic horses. Pharmaceu. Res. 29, 1650-1657

Koh Y. Y., Kim Y. W., Park J. D., Oh J. W. (1996) A comparison of serum haptoglobin levels between acute exacerbation and clinical remission in asthma. Clinical and experimental allergy: Brit. Soc. Allergy. Clin. Immunol. 26, 1202-1209

Koivunen A. L., Maisi P., Konttinen Y. T., Sandholm M. (1997a) Gelatinolytic activity in tracheal aspirates of horses with chronic obstructive pulmonary disease. Acta Vet. Scand. 38, 17-27

Koivunen A. L., Maisi P., Konttinen Y. T., Prikk K., Sandholm M. (1997b) Collagenolytic activity and its sensitivity to doxycycline inhibition in tracheal aspirates of horses with chronic obstructive pulmonary disease. Acta Vet. Scand. 38, 9-16

Koutsokera A., Stolz D., Loukides S., Kostikas K. (2012) Systemic biomarkers in exacerbations of COPD: the evolving clinical challenge. Chest 141, 396-405.

Krizkova S., Zitka O., Masarik M., Adam V., Stiborova M., Eckschlager T., Hubalek J., Kizek R. (2011) Clinical importance of matrix metalloproteinases. Bratisl. Med. J. 1 12, 435-40

Lavoie J. P., Martin J. G. (2005) Lung Remodeling in the Horse with Heaves. In: Ainsworth, McGorum, Viel, Robinson (Eds.), Third World Equine Airways Symposium. Ithaca: International Veterinary Information Service (www.ivis.org), Document No. P21 14.0705

Lavoie J. P., Léguillette R., Pasloske K., Charette L., Sawyer N., Guay D., Murphy T., Hickey G. J. (2002) Comparison of effects of dexamethasone and the leukotriene D4 receptor antagonist L-708,738 on lung function and airway cytologic findings in horses with recurrent airway obstruction. Am. J. Vet. Res. 63, 579-585

Lavoie J. P., Maghni K., Desnoyers M., Taha R., Martin J. G., Hamid Q. A. (2001) Neutrophilic airway inflammation in horses with heaves is characterized by a Th2-type cytokine profile. Am. J. Resp. Crit. Care Med. 164, 1410-1413

Lavoie-Lamoureux A., Leclere M., Lemos K., Wagner B., Lavoie J.-P. (2012a) Markers of systemic inflammation in horses with heaves. J. Vet. Int. Med. 26, 1419-1426

Lavoie-Lamoureux A., Beauchamp G., Quessy S., Martin J. G., Lavoie J. P. (2012b) Systemic inflammation and priming of peripheral blood leukocytes persist during clinical remission in horses with heaves. Vet. Immunol. Immunopathol. 146, 35-45

Lavoie-Lamoureux A., Moran K., Beauchamp G., Mavel S., Steinbach F., Lefebvre-Lavoie J., Martin J. G., Lavoie J.P. (2010) IL-4 activates equine neutrophils and induces a mixed inflammatory cytokine expression profile with enhanced neutrophil chemotactic mediator release ex vivo. Am. J. Physiol. Lung Cell. Molec. Physiol. 299, L472-L482

Lavoie-Lamoureux A., Maghni K., Lavoie J. P. (2010) Optimization of a procedure to accurately detect equine TNFalpha in serum samples. Vet. immunol. immunopathol. 138, 118-123

Leavell K. J., Peterson M. W., Gross T. J. (1996) The role of fibrin degradation products in neutrophil recruitment to the lung. Am. J. Resp. Cell Molec. Biol. 14, 53-60

Leclere M., Lavoie-Lamoureux A., Gelinas-Lymburner E., David F., Martin J. G., Lavoie J. P. (2011). Effect of antigenic exposure on airway smooth muscle remodeling in an equine model of chronic asthma. Am. J. Resp. Cell Molecul. Biol. 45, 181-187

Léguillette R., Desevaux C., Lavoie J. P. (2002) Effects of pentoxifylline on pulmonary function and results of cytologic examination of bronchoalveolar lavage fluid in horses with recurrent airway obstruction. Am. J. Vet. Res. 63, 459-463 
Lekeux P. und Duvivier D. (1991) Aerosol Therapy. In: Equine Respiratory Diseases. Available at : Internat. Vet. Inform. Service, Itha$\mathrm{ca}, \mathrm{New}$ York, USA

Lindberg A., Nasman-Glaser B., Lindgren J. A., Robinson N. E. (2002) Evaluation of leukotriene biosynthetic capacity in lung tissues from horses with recurrent airway obstruction. Am. J. Ve. Res. 63, 794-798

Marr K. A., Lees P., Cunningham F. M. (2002) Antigen challenge increases adherence of circulating neutrophils in horses with chronic obstructive pulmonary disease. Equine Vet. J. 34, 65-70.

Martin B. J., Reef V. B., Parente E. J., Sage A. D. (2000) Causes of poor performance of horses during training, racing, or showing: 348 cases (1992-1996). J. Am. Vet. Med. Assoc. 216, 554-558

Martin B. J., Reef V. B., Parente E. J., Sage A. D. (2000) Causes of poor performance of horses during training, racing, or showing: 348 cases (1992-1996). J. Am. Vet. Med. Assoc. 216, 554558

Mazan M. R., Hoffman A. M., Kuehn H., Deveney E. F. (2003) Effect of aerosolized albuterol sulfate on resting energy expenditure determined by use of open-flow indirect calorimetry in horses with recurrent airway obstruction. Am. J. Vet. Res. 64, 235-242

Miskovic M., Couetil L. L., Thompson C. A. (2007) Lung function and airway cytologic profiles in horses with recurrent airway obstruction maintained in low-dust environments. J. Vet. Int. Med. 21, 1060-1066

Monreal L., Anglés A., Espada Y., Monasterio J., Monreal M. (2000) Hypercoagulation and hypofibrinolysis in horses with colic and DIC. Equine Vet. J. 32 (Suppl), 19-25

Moore B. R., Krakowka S., Robertson J. T., Cummins J. M. (1995) Cytologic evaluation of bronchoalveolar lavage fluid obtained from standardbred racehorses with inflammatory airway disease. Ame. J. Vet. Res. 56, 562-567

Müller B., White J. C., Nylén E. S., Snider R. H., Becker K. L., Habener J.F. (2001) Ubiquitous expression of the calcitonin-I gene in multiple tissues in response to sepsis. Clin. Endocrinol. Metabol. 86, 396-404

Nakstad B., Lyberg T., Skjonsberg O. H., Boye N. P. (1990) Local activation of the coagulation and fibrinolysis systems in lung disease. Thrombosis research 57, 827-838

Naito Y., Yoshikawa T. (2005) Role of matrix metalloproteinases in inflammatory bowel disease. Molecul. Asp. Med. 26, 379-90

Nevalainen M., Raulo S. M., Brazil T. J., Pirie R. S., Sorsa T., McGorum B. C., Maisi P. (2002) Inhalation of organic dusts and lipopolysaccharide increases gelatinolytic matrix metalloproteinases (MMPs) in the lungs of heaves horses. Equine Vet. J. 34, 150-155

Newton J. R., Wood J. L. (2002) Evidence of an association between inflammatory airway disease and EIPH in young Thoroughbreds during training. Equine Vet. J. 34, 417-424

Niedzwiedz A., Nicpon J., Borowicz H., Los P., Zawadzki M., Januszewska L. (2011) Evaluation of selected antioxidant enzymes in the blood of horses with recurrent airways obstruction. Medycyna weterynaryina 67, 129-132

Niu W. Y., Wan Y. G., Li M. Y., Wu Z. X., Zhang L. G., Wang J. X. (2013) The diagnostic value of serum procalcitonin, IL-10 and Creactive protein in community acquired pneumonia and tuberculosis. Europ. Review Med. Pharmacol. Sci. 17, 3329-3333

Oka S., Furukawa H., Shimada K., Hayakawa H., Fukui N., Tsuchiya N., Tohma S. (2013) Serum biomarker analysis of collagen disease patients with acute-onset diffuse interstitial lung disease. BMC Immunol. 14, 9

Pereira J. M., Teixeira-Pinto A., Basílio C., Sousa-Dias C., Mergulhão P., Paiva J. A. (2013) Can we predict pneumococcal bacteremia in patients with severe community-acquired pneumonia? Crit. Care 28, 970-974

Parks W. C., Wilson C. L., López-Boado Y. S. (2004) Matrix metalloproteinases as modulators of inflammation and innate immunity. Nature Rev. Immunol. 4, 617-29

Pascoe J. R., Ferraro G. L., Cannon J. H., Arthur R. M., Wheat J. D. (1981) Exercise induced pulmonary hemorrhage in racing thoroughbreds: a preliminary study. Am. J. Vet. Res. 42, 703-707
Picandet V., Léguillette R., Lavoie J. P. (2003) Comparison of efficacy and tolerability of isoflupredone and dexamethasone in the treatment of horses affected with recurrent airway obstruction ("heaves"). Equine Vet. J. 35, 419-424

Pirie R. S. (2014) Recurrent airway obstruction: A review. Equine Vet. J. DOI: $10.1111 /$ evj.12204

Pirie R. S., Collie D. D., Dixon P. M., McGorum B. C. (2002) Evaluation of nebulised hay dust suspensions (HDS) for the diagnosis and investigation of heaves. 2: Effects of inhaled HDS on control and heaves horses. Equine Vet. J. 34, 337-342

Raphel C. F., Soma L. R. (1982) Exercise-induced pulmonary hemorrhage in Thoroughbreds after racing and breezing. Am. J. Vet. Res. $43,1123-1127$

Ratjen F., Hartog C. M., Paul K., Wermelt J., Braun J. (2002) Matrix metalloproteases in BAL fluid of patients with cystic fibrosis and their modulation by treatment with dornase alpha. Thorax 57: 930-4

Raulo S. M., Sorsa T., Tervahartiala T., Pirila E., Maisi P. (2001a) MMP-9 as a marker of inflammation in tracheal epithelial lining fluid (TELF) and in bronchoalveolar fluid (BALF) of COPD horses. Equine Vet. J. 33, 128-136

Raulo S. M., Sorsa T. A., Kiili M. T., Maisi P. S. (2001 b) Evaluation of collagenase activity, matrix metalloproteinase-8, and matrix metalloproteinase-13 in horses with chronic obstructive pulmonary disease. Am. J. Vet. Res. 62, 1142-1148

Ribera T., Monreal L., Armengou L., Ríos J., Prades M. (2011) Synovial fluid D-dimer concentration in foals with septic joint disease. J. Vet. Int. Med. 25, 1113-1117

Rickards K. J., Page C. P., Cunningham F. M. (2004) Allergen challenge alters lymphocyte phosphodiesterase activity in horses with heaves. Pulmon. Pharmacol. Therap. 17, 163-172

Rickards K. J., Page C. P., Lees P., Gettinby G., Cunningham F. M. (2003) In vitro and ex vivo effects of the phosphodiesterase 4 inhibitor, rolipram, on thromboxane production in equine blood. Vet. Pharmacol. Therap. 26, 123-130

Rieger M., Kochleus C., Teschner D., Rascher D., Barton A., Geerlof A., Kremmer E., Schmid M., Hartmann A., Gehlen H. (2014) A new ELISA for the quantification of equine Procalcitonin in plasma for the evaluation of Procalcitonin as possible inflammation marker in horses. Analytical and Bioanalytical Chemistry, submitted.

Robinson N. E. (2003) Inflammatory airway disease: defining the syndrome. Conclusions of the Havemeyer workshop. Equine Vet. Educ. 15, 61-63

Robinson N. E., Jackson C., Jefcoat A., Berney C., Peroni D., Derksen F. J. (2002a) Efficacy of three corticosteroids for the treatment of heaves. Equine Vet. J. 34, 17-22

Robinson N. E., Jefcoat A. M., Gerber V. (2002b) Mucus and inflammation in equine heaves. Pferdeheilkunde 18: 551-556

Robinson N. E. (ed.) (2001) International workshop on equine chronic airway disease, Michigan State University 16-18 June 2000. Equine Vet. J. 33, 5-19

Robinson N. E., Jackson C. A., Peroni D., Stanley S., Kollias-Baker C., Jefcoat A. M., Berney C. E., Derksen F. J. (2000a): Why is oral prednisone ineffective for treatment of heaves? Proc. Am. Assoc. Equine Pract. 46, 266-267

Robinson N. E., Olszewski M. A., Boehler D., Berney C., Hakala J., Matson C., Derksen F. J. (2000b) Relationship between clinical signs and lung function in horses with recurrent airway obstruction (heaves) during a bronchodilator trial. Equine Vet. J. 32, 393-400

Rosenberg S. R., Kalhan R. (2012) Biomarkers in chronic obstructive pulmonary disease. Transl. Res. Labor: Clin. Med. 159, 228-237

Rush B. R., Raub E. S., Thomsen M. M., Davis E. G., Matson C. J., Hakala J. E. (2000) Pulmonary function and adrenal gland suppression with incremental doses of aerosolized beclomethasone dipropionate in horses with recurrent airway obstruction. J. Am. Vet. Med. Assoc. 217, 359-364

Russell R. E., Culpitt S.V., DeMatos C., Donnelly L., Smith M. (2002) Release and activity of matrix metalloproteinase- 9 and tissue inhibitor of metalloproteinase-1 by alveolar macrophages from patients with chronic obstructive pulmonary disease. Am. J. Resp. Cell Molec. Biol. 26, 602-609 
Sánchez A., Couëtil L. L., Ward M. P., Clark S. P. (2005) Effect of airway disease on blood gas exchange in racehorses. J. Vet. Int. Med. 19, 87-92

Sandersen C., Bureau F., Turlej R., Fiévez L., Dogné S., Kirschvink N., Lekeux P. (2001) Homodimer activity in distal airway cells determines lung dysfunction in equine heaves. Vet. Immunol. Immunopathol. 80, 315-326

Schanen J. G., Iribarren C., Shahar E., Punjabi N. M., Rich S. S., Sorlie P. D., Folsom A. R. (2005) Asthma and incident cardiovascular disease: The Atherosclerosis Risk in Communities Study. Thorax 60, 633-638

Schusser G. F., Wiegand M., Ruhland A. (1999) Technique and cell differential in bronchoalveolar lavage of horses with COPD. Prakt. Tierarzt 80, 601-604

Seeger W., Elssner A., Gunther A., Kramer H. J., Kalinowski H. O. (1993) Lung surfactant phospholipids associate with polymerizing fibrin: loss of surface activity. Am. J. Resp. Cell Mol. Biol. 9, 213220

Seeger W., Stöhr G., Wolf H. R., Neuhof H. (1985) Alteration of surfactant function due to protein leakage: special interaction with fibrin monomer. Appl. Physiol. 58, 326-338

Shapiro S. D., Endicott S. K., Province M. A., Pierce J. A., Campbell E. J. (1991 a) Marked longevity of human lung parenchymal elastic fibers deduced from prevalence of D-aspartate and nuclear weapons-related radiocarbon. Clin. Invest. 87, 1828-34

Shapiro S. D., Campbell E. J., Welgus H. G., Senior R. M. (1991b) Elastin degradation by mononuclear phagocytes. Ann. New York Acad. Sc. 624, 69-80

Simonen-Jokinen T., Pirie R. S., McGorum B. C., Maisi P. (2005a) Effect of composition and different fractions of hay dust suspension on inflammation in lungs of heaves-affected horses: MMP-9 and MMP-2 as indicators of tissue destruction. Equine Vet. J. 37, 412 417

Simonen-Jokinen T., Pirie R. S., McGorum B., Maisi P. (2005b) Dose responses to inhalation of endotoxin, hay dust suspension and Aspergillus fumigatus extract in horses as measured by levels and activation of matrix metalloproteinase-9. Equine Vet. J. 37, 155160

Sin D. D., Anthonisen N. R., Soriano J. B., Agusti A. G. (2006) Mortality in COPD: Role of comorbidities. European Respiratory Journal 28,1245-1257

Sitrin R. G., Pan P. M., Srikanth S., Todd R. F. (1998) Fibrinogen activates NF-kappa B transcription factors in mononuclear phagocytes. Journal of Immunology 161, 1462-1470

Song Y., Klevak A., Manson J. E., Buring J. E., Liv S. (2010) Asthma, chronic obstructive pulmonary disease, and type 2 diabetes in the Women's Health Study. Diabetes Research and Clinical Practice 90, 365-371

Tang J., Long W., Yan L., Zhang Y., Xie J., Lu G., Yang C. (2013) Procalcitonin guided antibiotic therapy of acute exacerbations of asthma: a randomized controlled trial. BMC Infectious Disease 13,596

Tremblay G. M., Ferland C., Lapointe J. M., Vrins A., Lavoie J.P., Cormier Y. (1993) Effect of stabling on bronchoalveolar cells obtained from normal and COPD horses. Equine Veterinary Journal 25, 194-197

Ugarte-Gil C. A., Elkington P., Gilman R. H., Coronel J., Tezera L. B., Bernabe-Ortiz A., Gotuzzo E., Friedland J. S., Moore D. A. (2013) Induced sputum MMP-1, -3 \& -8 concentrations during treatment of tuberculosis. PLoS One. 8: e61333

Viel L. (1980) Structural-functional correlations of the lung in the normal light horse. M.Sc., Thesis, University of Guelph, Guelph ON, Canada

Walsh E. E., Swinburne A. J., Becker K. L., Nylen E. S., Snider R. H., Baran A., Peterson D. R., Falsey A. R. (2013) Can serum procalcitonin levels help interpret indeterminate chest radiographs in patients hospitalized with acute respiratory illness? Journal of Hospital Medicine 8, 61-67

Ware L. B., Bastarache J. A., Wang L. (2005) Coagulation and fibrinolysis in human acute lung injury - new therapeutic targets? The Keio Journal of Medicine 54, 142-149
Winder N. C., Grünig G., Hermann M., von Fellenberg R. (1990) Fibrin/fibrinogen in lungs and respiratory secretions of horses with chronic pulmonary disease." Am. J. Vet. Res. 51, 945-949

Wood J. L., Newton J. R., Chanter N., Mumford J. A. (2005) Association between respiratory disease and bacterial and viral infections in British racehorses. Clin. Microbiol. 43, 120-126

Wu T. L., Chang P. Y., Tsao K. C., Sun C. F., Wu L. L., Wu J. T. (2007) A panel of multiple markers associated with chronic systemic inflammation and the risk of atherogenesis is detectable in asthma and chronic obstructive pulmonary disease. Clin. Lab. Anal. 21, 367-371

Yende S., Waterer G. W., Tolley E. A., Newman A. B., Baver D. C., Taaffe D. R., Jensen R., Crapo R., Rubin S., Nevitt M., Simonsick E. M., Satterfield S., Harris T., Kritchevsky S. B. (2006) Inflammatory markers are associated with ventilatory limitation and muscle dysfunction in obstructive lung disease in well functioning elderly subjects. Thorax 61, 10-16

Zhao Y. F., Jiang Y. P., Zhou L. F., Wu X. L. (2013) Prognostic Value of Chronic Obstructive Pulmonary Disease Assessment Test, Serum Copeptin, Procalcitonin and C-reactive Protein: Six Months of Outcome in Patients With Acute Exacerbation of Chronic Obstructive Pulmonary Disease. Am. J. Med. Sci. 2013 Nov 21. [Epub ahead of print]

Deutsche Übersetzung

\section{Diagnostischer Wert} verschiedener Entzündungsmarker
bei chronischen Atemwegs-
erkrankungen des Pferdes -
eine Literaturübersicht

Einleitung

Erkrankungen des Atmungsapparates, vor allem der tiefen Atemwege, stellen die häufigste diagnostizierte Ursache für vorberichtliche Leistungsinsuffizienz beim Sportpferd dar (Allen et al. 2006, Martin et al. 2000). Beim Rennpferd haben das belastungsinduzierte Lungenbluten (EIPH, exercise induced pulmonary haemorrhage) und die "inflammatory airway disease" (IAD) die höchste Prävalenz. (Wood et al. 2005, Pascoe et al. 1981, Raphel und Soma 1982, Newton und Wood 2002). Beim Warmblutpferd kommen IAD und EIPH ebenfalls vor, von noch größerer Bedeutung ist jedoch die Chronisch obstruktive Bronchitis (COB), in der englischsprachigen Literatur in ihrer schubartig verlaufenden Form als Recurrent Airway Obstruction (RAO) bezeichnet (Robinson 2001). Sie stellt die häufigste Ursache vorberichtlichen chronischen Hustens und Leistungsinsuffizienz dar (Pirie 2014). Ihre Prävalenz wurde in der nördlichen Hemisphere auf 10$20 \%$ geschäłz† (Hotchkiss et al. 2007). Die Erkrankungshäufigkeit steigt mit dem Alter und ist abhängig von der Haltungsform. Sie ist somit eine häufige Ursache für das Ausscheiden des Pferdes aus dem Sport (Deegen 1986, Lekeux und Duvivier 2004).

Die Diagnostik tiefer Atemwegserkrankungen beruht seit der Entwicklung der Fiberoptikendoskopie und der erstmaligen Beschreibung der Technik der transendoskopischen bronchoaolveolären Lavage (Viel 1980) neben der klinischen Untersuchung des Atmungsapparates und der Untersuchung der 
Lungenfunktion vor allem auf der zytologischen und mikrobiologischen Untersuchung von Tracheobronchialsekret (TBS) und bronchoalveolärer Lavageflüssigkeit (BALF). Obwohl die $\mathrm{RAO}$ in Exazerbation mit deutlichen Symptomen verbunden ist, ergeben sich im Klinikalltag häufiger Probleme in der Diagnostik, da nur wenige Patienten in Exazerbation vorgestellt werden. Auch die IAD verläuft in vielen Fällen subklinisch (Covëtil et al. 2007). Nichtsdestotrotz wird die IAD als mögliche Vorläufererkrankung für die RAO diskutiert.

In diesen Fällen stößt die bisherige Diagnostik oft an ihre Grenze, daher wurde in zahlreichen Studien versucht, verschiedene Entzündungsmarker für die Erkrankungen der tiefen Atemwege zu etablieren. Neben den lokalen inflammatorischen Prozessen scheint es insbesondere bei der RAO auch eine systemische Beteiligung zu geben, was auch vom humanen Asthma bronchiale (Biermer 2007) und der Chronic Obstructive Pulmonary Disease (COPD) (Rosenberg und Kalha 2012, Koutsokera et al. 2012) bekannt ist. Daher gilt es, nicht nur Marker für die pulmonale durch neutrophile Granulozyłen dominierte Entzündung zu finden, sondern auch nach der systemischen Beteiligung des Organismus zu suchen, da pro-inflammatorische Zustände den Krankheitsverlauf in den tiefen Atemwegen beeinflussen können.

\section{Lokale Entzündungsmarker in TBS und BALF}

Die Neutrophilie in TBS und BALF ist ein ausgeprägtes zyłologisches Merkmal der Entzündung bei der IAD und vor allem bei der RAO, bei der es innerhalb weniger Stunden zu einem Einstrom neutrophiler Granulozyten in die terminalen Atemwege kommt, gefolgt von einer Spätphase der Migration. Die Teilnehmer des Havemeyer Foundation Workshop (Robinson 2003) schlugen Normalwerte von 60\% Makrophagen, $35 \%$ Lymphozyten, <5\% neutrophile Granulozyten, <2\% Mastzellen, $<0,1 \%$ Eosinophile sowie keine oder vereinzelt vorkommende Epithelzellen für das gesunde Pferd in der BALF vor. Bei der RAO in Exazerbation zeigen die Pferde eine Ruhedyspnoe mit einem maximalen Interpleuraldruckdifferenz von $>15 \mathrm{~cm} \mathrm{H}_{2} \mathrm{O}$ durch Bronchokonstriktion, Schleimhautschwellung und Sekretansammlungen (Pirie 2014), sowie eine Entzündung in den kleinen Atemwegen mit einem prozentualen Anteil von mindestens $25 \%$ an neutrophilen Granulozyten am BALF-Zellgehalt (Robinson 2001). Auch die definitive Diagnose einer IAD beruht derzeit vor allem auf der BALF Zytologie (Couëtil et al. 2007), welche gekennzeichnet ist durch einen Anstieg der Gesamtzellzahl mit einer geringgradigen Neutrophilie (Fogarty und Buckley 1991, Moore et al. 1995, Couëtil und Denicola 1999, Holcombe et al. 2001) oder Lymphozytose (Moore et al. 1995, Covëtil et al. 2001, Sánchez et al. 2005) oder alternativ, durch einen erhöhten Mastzell- (Hare et al. 1994, Hoffman et al. 1998) oder Eosinophilenanteil (Hare und Viel 1998). Die Abgrenzung zur RAO in Exazerbation erfolgt über die fehlende Ruhedyspnoe (Robinson 2003) und fehlendes Ansprechen auf eine Provokation mit schimmeligem Heu (Dixon et al. 1995). Eine Möglichkeit zur Abgrenzung zwischen IAD und RAO in Remission existiert außer einer solchen Provokation jedoch bislang nicht.

Der immunologische Hintergrund der RAO bleibt trotz vieler Studien zur Pathogenese (Lindberg et al. 2002, Ainsworth et al. 2003, Ainsworth et al. 2002, Gerber et al. 2003), aber auch zur therapeutischen Beeinflussung der Exazerbation (Jackson et al. 2000, Robinson et al. 2000a und 2000b, Rush et al. 2000, Henrikson und Rush 2001, Leguillette et al. 2002, Lavoie et al. 2002, Robinson et al. 2002a und 2002b, Picandet et al. 2003, Mazan et al. 2003, Rickards et al. 2003, Robinson et al. 2003) nicht vollständig geklärt. Auch wenn sich Hinweise auf einen Th-2 basierte Hypersensitivitätsreaktion vom Allergietyp IV häufen (Lavoie et al. 2001, Beadle et al. 2002, Cordeau et al. 2004), gibt es auch Studienergebnisse, die auf eine Th- 1 vermittelte Immunreaktion schließen lassen. Erhöhte Level von Interleukin 4 und 5 sowie eine Unterdrückung der Interferon- $\gamma$ Expression sprechen für einen Th-2 Hintergrund (Cordeau et al. 2004). Lavoie et al. (2001) konnten zeigen, dass rekombinantes equines Interleukin-4 zu morphologischen Veränderungen an neutrophilen Granulozyten im Blut führt, und die Effekte von Lipopolysacchariden und Tumer-Nekrose-Faktor- $\alpha$ auf die Interleukin- 8 Expression durch pulmonale arterielle Endothelzellen verstärkt. Auf den Neutrophilen RAO-erkrankter Pferde konnten zwar nicht mehr Rezeptoren für Interleukin-4 nachgewiesen werden als bei gesunden Pferden, jedoch eine genetische Verbindung zwischen einem Polymorphismus des Interleukin-4 Rezeptors- $\alpha$ auf Chromosom 13 und RAO sowie eine erhöhte Expression dieses Rezeptors in einer Familie mit hoher RAO Prävalenz im Vergleich zu einer anderen Familie (Gerber et al. 2008). Auf der anderen Seite wiesen Ainsworth et al. (2003) eine erhöhte Interferon- $\gamma$ Produktion in BAL Zellen nach, was eher einen Th-1 basierten Hintergrund nahelegt, und weitere Autoren konnten für keinen der beiden Typen Hinweise finden (Kleiber et al. 2005). Durch die Inhalation spezifischer bakterieller DNA-Abschnitte mit immunmodulatorischer Wirkung (CpGNanopartikel) konnte jedoch das Zytokinprofil bei RAOPatienten in Richtung eines Th-1 Profils verschoben werden, was zu einer deutlichen Abnahme der klinischen Symptomatik und einer Reduktion der Neutrophilen im TBS führte (Klier et al. 2012).

Besondere Bedeutung in der Chemotaxis neutrophiler Granulozyten scheint dem Interleukin-8 zuzukommen, welches bereits wenige Stunden nach Umstellung von Grassilage auf $\mathrm{Heu}$ als Rauhfutter in der BALF in erhöhter Konzentration nachgewiesen werden konnte (Franchini et al. 2000). In der chronischen Entzündungsphase scheinen aber auch Interleukin- 17 (Debrue et al. 2005) und Interleukin- 1 B und 23 (Ainsworth et al. 2007) eine Rolle zu spielen.

Während der prozentuale Anteil der neutrophilen Granulozyten außerhalb einer Phase der Exazerbation bei RAO-kranken Pferden schnell in den Referenzbereich fällt und die Erkrankung somit zytologisch nicht mehr nachweisbar ist, bleibt die Myeloperoxidase, ein Enzym der neutrophilen Phagozytosereaktion, welches im Rahmen der Bildung von reaktiven Saverstoffmetaboliten gebildet wird, in der BALF bei RAO-Patienten sowohl in Exazerbation als auch in Remission signifikant höher als bei gesunden Kontrolltieren (Art et al. 2006). Die Myeloperoxidase stellt somit einen sensiblen Entzündungsmarker auch bei subklinischen Patienten dar (Fey 2004). Im Einklang damit konnte in verschiedenen Studien eine reduzierte anti-oxidative Kapazität bei RAO-Patienten in Exazerbation durch niedrige Askorbinsäurekonzentrationen in der BALF nachgewiesen werden Beim Abklingen einer Exazerbation wurde eine erhöhte Glutathion Peroxidase Akti- 
vität nachgewiesen, vermutlich um dem oxidativen Stress entgegenzuwirken (Deaton et al. 2006). Auch in der Ausatemluft konnten während einer Exazerbation, nicht aber nach kurzzeitiger Inhalation organischen Staubes, erhöhte Marker oxidativen Stresses festgestellt werden (Deaton et al. $2005 \mathrm{~b}$ und 2006b).

\section{Systemische Entzündungsmarker im Blut}

Die pulmonale von neutrophilen Granulozyten dominierte Entzündungsreaktion während der Exazerbation einer RAO wurde in zahlreichen Studien untersucht. Sie ist weitgehend reversibel durch die Vermeidung des Antigenkontaktes unter konsequenter Haltungsoptimierung (Robinson 2001). Nichtsdestotrotz besteht der Verdacht, dass auch in der Phase der Remission ein unterschwelliger Entzündungsprozess aufrecht erhalten bleibt, da auch bei asymptomatischen Pferden eine leichte periphere Bronchokonstriktion, eine erhöhte Zellerneverungsrate der glatten Muskelzellen um die Bronchiolen und eine höhere Aktivität nachgewiesen wurden (Leclere et al. 2011, Miskovic et al. 2007, Sandersen et al. 2001). NF-KB ist ein spezifischer Transkriptionsfaktor, der eine Schlüsselfunktion bei entzündlichen Prozessen hat. In der Phase der Exazerbation wurden eine Aktivierung peripherer Leukozyten und erhöhte Konzentrationen verschiedener Entzündungsmarker in der Blutbahn gefunden (Lavoie-Lamoureux et al. 2010, Rickards et al. 2004, Marr et al. 2002, Kirschvink et al. 2002, Gray et al. 1989), so dass die inflammatorischen Abläufe nicht ausschließlich auf die Lunge begrenzt zu sein scheinen. Auch das humane Asthma bronchiale, welches pathophysiologisch der equinen RAO ähnelt, wird als systemische Erkrankung angesehen, da auch hier zahlreiche Entzündungsmarker im Blut nachgewiesen werden konnten (Bjermer 2007). Dazu gehörten sowohl Mediatoren des Immunsystems (Zytokine, Eikosanoide, Cyclooxygenase Metaboliten und lgE) als auch akute Phase Proteine wie das C-reaktive Protein, Haptoglobin, Fibrinogen und Serumamyloid A (Kasayama et al. 2009, Wu et al. 2007, Koh et al. 1996). Auch bei der humanen COPD (Chronic obstructive pulmonary disease), welche ebenfalls gemeinsame Merkmale mit der equinen RAO aufweist, konnten zahlreiche Entzündungsmarker wie das Fibrinogen oder das Creaktive Protein systemisch nachgewiesen werden (Rosenberg und Kalha 2012, Koutsokera et al. 2012). Es wird angenommen, dass systemische inflammatorische Prozesse die CoMorbidität bei Patienten mit chronischen Atemwegserkrankungen erhöhen (Bjermer 2007, Schanen et al. 2005, Song et al. 2010, Sin et al. 2006, Yende et al. 2006).

Die systemischen inflammatorischen Prozesse bei der RAO des Pferdes sind bislang jedoch wenig untersucht. LavoieLamoureux et al. (2012a) verglichen verschiedene AkutePhase-Proteine (Haptoglobin, Serumamyloid A, C-reaktives Protein) und Zytokine (Interleukin-2, -4 und - 10 sowie Interferon- $\alpha$ und $-\beta$ ) im Serum zwischen gesunden Pferden und RAO-Patienten über eine 30-tägige Exposition von $\mathrm{Heu}$ und Stroh. Haptoglobin stellte sich dabei als geeigneter Marker für eine akute und chronische und Serumamyloid A für die akute Entzündungsreaktion heraus, während sämtliche untersuchten Zytokine keinen signifikanten Unterschied zwischen den Gruppen aufwiesen. In einer anderen Studie wurden hingegen erhöhte TNF- $\alpha$ Konzentrationen nach ex vivo Stimulation mit Bakterienprodukten bei RAO-Pferden nachge- wiesen (Lavoie-Lamoureux et al. 2012b). Niedzwiedz et al. (2011) konnten erhöhte Marker für oxidativen Stress im peripheren Blut während der Exazerbation im Vergleich zu Kontrolltieren nachweisen.

Bereits seit den 1970er Jahren wird im Zusammenhang mit Sepsis als weiteres Symptom die Hypocalcämie untersucht. Dies ist darauf zurückzuführen, dass bei einer Sepsis Procalcitonin (PCT) in hohen Konzentrationen im Blut und in fast allen Geweben vieler Organe exprimiert wird (Müller et al. 2001). PCT ist das Vorläuferprotein des Hormons Calcitonin, welches den Calciumhaushalt der Zellen reguliert, indem es die Aktivität der Osteoklasten hemmt. Bei gesunden Individuen wird Preprocalcitonin (prePCT) ausschließlich in den CZellen der Schilddrüse produziert. Akute lokale Prozesse in der Lunge führen zwar zu deutlich niedrigeren PCT Konzentrationen im Plasma als bei Sepsis, eine Differenzierung zwischen verschiedenen Lungenerkrankungen ist beim Menschen aber dennoch möglich (Pareira et al. 2013, JuliánJiménez et al. 2013, Berg und Lindhardt 2012). So wurde PCT z.B. bei der Differenzierung der Tuberkulose von anderen Pneumonien erfolgreich eingesetzt (Niv et al. 2013).

Auch bei chronischen Lungenerkrankungen des Menschen wie dem Asthma bronchiale konnten erhöhte PCT Konzentrationen festgestellt werden. Bei akuter Exazerbation treten dabei oft zusätzlich bakterielle Infektionen der tiefen Atemwege auf. РCT kann hier bei der Entscheidung für oder gegen Antibiotika in der Therapie eingesetzt werden sowie bei der Interpretation indifferenter Röntenaufnahmen des Thorax helfen (Tang et al. 2013, Walsh et al. 2013). Auch bei der COPD (Chronic obstructive pulmonary disease) kann PCT bei der Entscheidung einer individuellen Therapie mit Antibiotika oder Glukokortikoiden hilfreich sein (Brightling 2013). Auch in der Verlaufskontrolle der COPD wurde PCT bereits erfolgreich eingesetzt (Zhao et al. 2013).

Rieger et al. (2014, akzeptiert) etablierten einen ELISA für equines PCT und konnten bei septischen Pferden deutlich erhöhte Werte im Vergleich zu gesunden Kontrolltieren nachweisen. Möglicherweise ist PCT auch als Marker für chronische Pneumopathien des Pferdes geeignet.

\section{Koagulation und Fibrinolyse}

Chronisch obstruktive Pneumopathien führen langfristig zu chronischen Umbauprozessen der Bronchienwände und des Lungenparenchyms, die mit der Bildung von Fibrosen einhergehen (Kaup et al. 1990a und 1990b, Lavoie et al. 2005, Ainsworth 2010). Dieses Remodelling wird durch prokoagulatorische Verhältnisse begünstigt, wohingegen die Fibrinolyse zur Abtragung von alveolären Fibrinablagerungen beiträgt und somit diesem Mechanismus entgegenwirkt (Seeger et al. 1985).

Bei mechanischen oder entzündlichen Schädigungen, bei denen die natürlichen Barrieren wie das Kapillarendothel und insbesondere auch das Alveolarepithel geschädigt werden, kommt es initial zu einem Übertritt von Plasmaproteinen und zu einer verstärkten Gerinnungsaktivierung mit vermehrter Fibrinbildung. Dies ist Teil des natürlichen Heilungs- und Reparaturmechanismus und dient als primärer Verschluss der geschädigten Membranen (Günther et al. 2000). Wenn die Gerinnungs- 
prozesse jedoch im Übermaß ablaufen und dazu noch für längere Zeit persistent sind, schlägt dieser Heilungsmechanismus in einen pathologischen Prozess um, der langfristig zu daverhaften Fibrinablagerungen und Fibrosierung führt und damit erheblichen negativen Einfluss auf die Pathogenese und den Verlauf verschiedenster respiratorischer Erkrankungen hat (Akinnusi und El Solh 2007, Nakstad et al. 1990).

Neben der Begünstigung von Fibrosierungsprozessen haben das gebildete Fibrin und seine Derivate auch Auswirkungen auf andere Pathomechanismen der Entzündung und damit Einfluss auf den Verlauf der inflammatorischen Prozesse und Reparaturen von geschädigtem Lungengewebe (/del/ 2003). So begünstigen Fibrinderivate unter anderem die Migration von Entzündungszellen und die Adhäsion sowie Proliferation von Fibroblasten mit nachfolgender Kollagenproduktion (Leavell et al. 1996, Ciano et al. 1986). Das Fibrinogenmolekül ist an der Modulation der Entzündungsantwort beteiligt, indem es an Monozyten bindet und dadurch Transkriptionsfaktoren wie NF$\kappa \mathrm{B}$ aktiviert, was wiederum eine verstärkte pro-inflammatorische Zytokinproduktion zur Folge hat (Sitrin et al. 1998). Darüber hinaus führen Fibrin und seine Derivate zu einer Inhibierung von Surfactant, wodurch die Oberflächenspannung an den Alveolen verloren geht, es zu Mikroatelektasen und damit zu einer Beeinträchtigung des Gasaustausches kommt. Diese Dysfunktion entsteht zum einen durch den Einschluss von Surfactantkomponenten in die Fibrinmatrix und eine dadurch gestörte Funktion des Hauptphospholipides DPPC (Dipalmitoylphosphatidylcholin, Seeger et al. 1993) und zum anderen durch Wechselwirkung mit Fibrinogen, Fibrinmonomeren und anderen Proteinen, wobei die Fibrinmonomere die stärkste Hemmwirkung besitzen (Seeger et al. 1985).

In der Humanmedizin wurde schon früh die Hypothese aufgestellt, dass es bei respiratorischen Erkrankungen, die mit einer Schädigung der Alveolen einhergehen, zu einer Dysbalance zwischen koagulatorischer und fibrinolytischer Aktivität im Extravasalraum kommen muss. Untersuchungen mit den verschiedenen Parametern der Fibrinolyse wie des u-PA (Urokinase-Typ Plasminogenaktivator), des PAl- 1 (Pasminogen Aktivator Inhibitor 1), des $\alpha 2$-AP ( $\alpha 2$-Antiplasmin) sowie der DDimere zeigten eine Verschiebung hin zur vermehrten Koagulation in der bronchoalveolären Lavageflüssigkeit (BALF) bei Patienten mit chronischen Lungenerkrankungen (Günther ef al. 2000). Durch zahlreiche weiterführende Studien in der Humanmedizin gilt die Bedeutung von Fibrinolyse und Koagulation für den Pathomechanismus verschiedener Lungenerkrankungen als gesichert, so dass die Entwicklung fibrinolysefördernder Therapeutika als vielversprechend angesehen wird (Ware et al. 2005).

In der Veterinärmedizin allgemein und speziell an der Lunge des Pferdes wurde bislang auf diesem Gebiet nur wenig geforscht. Jedoch ist bekannt, dass es auch beim Pferd mit chronischen Lungenerkrankungen zu Fibrinogen- und Fibrinansammlungen in den verdickten Alveolarsepten kommt (Winder et al. 1990). Auch konnten bei einem ausgeprägten Krankheitsbild höhere Werte an löslichen Fibrinogenabbauprodukten, Proteasen und prokoagulatorischer Aktivität in Sekreten des Respirationstraktes nachgewiesen werden. Die Ergebnisse dieser Studie (Winder et al. 1990) lassen vermuten, dass es auch bei der RAO des Pferdes zu einer Dysbalance in der extravasalen Hämostase kommt, die sich durch ver- mehrte Fibrinablagerungen, nachfolgende Fibrosierung sowie einer damit einhergehenden Funktionsstörung des Surfactant negativ auf den Krankheitsverlauf auswirkt. In anderen Organsystemen des Pferdes wurde die Bedeutung der Fibrinolyse bereits eingehender untersucht, z.B. in Plasma und in Peritonealflüssigkeit bei Pferden mit Kolik (Delgado et al. 2009, Monreal et al. 2000) und in Synovialflüssigkeit bei Fohlen mit Arthritis (Ribera et al. 2011).

\section{Extrazelluläres Remodelling}

Die extrazelluläre Matrix (ECM) des Lungenbindegewebes unterliegł ständigen Umbauprozessen im Rahmen von Wachstum und Regeneration. Um das Gewebe zu erhalten, muss ein Gleichgewicht zwischen Abbau und Resynthese extrazellulärer Matrixstrukturen bestehen, wobei der Abbau durch Metalloproteinasen erfolgt (Clutterbuck et al. 2010). Das pulmonale Interstitium bildet das mechanische Gerüst der Lunge, während die Basalmembran die alveolären Epithelzellen unterstützt und zumindest teilweise die Resistenz der Diffusionsbarriere bestimmt (Dunsmore und Rannels 1996). Die primären strukturellen Fibrillen der Lunge bestehen aus Kollagen vom Typ-I und Elastin. Elastinfasern sind sehr stabil, dehnbar und haben eine hohe Lebensdaver (Shapiro et al. 1991a). Die Alveolarwand besteht aus Kollagen vom Typ-III (Foroniy et al. 2003), während die Basalmembran hauptsächlich aus Typ-IV besteht. Große Kollagen- und Elastinfasern sind durch kleinere Fibrillen miteinander verbunden. Die Degradierung primärer Strukturfibrillen betrifft daher zunächst die Spaltung dieser quervernetzenden Fibrillen (Shapiro et al. $1991 \mathrm{~b})$. Da verschiedene Enzyme am Turnover der ECM beteiligt sind, ist die Bedeutung einzelner Proteasen o.a. Enzyme schwer zu bestimmen.

Die Funktion der Matrix Metalloproteinasen (MMPs) wurde bereits vor fünfzig Jahren erstmalig beschrieben (Gross und Lapiere 1962). MMPs spielen bei vielen physiologischen, aber auch pathologischen Prozessen eine entscheidende Rolle in der Umstrukturierung der extrazellulären Matrix, Gewebedegradierung, Reparaturmechanismen und Zellmigration (Ratjen et al. 2002). Am besten untersucht ist ihre physiologische Funktion beim Ab-und Aufbau von Kollagen und Elastin im Bindegewebe (Krizkova et al. 2011 ). MMPs sind an vielen inflammatorischen Prozessen beteiligt, indem sie physikalische Barrieren regulieren, inflammatorische Mediatoren wie Zytokine und Chemokine modulieren und somit Chemokingradienten im entzündeten Gewebe etablieren, die die Leukozytenkonzentrationen am Infektionsherd stevern (Naito and Yoshikawa 2005).

Von einer Bedeutung der Metalloproteinasen bei Pneumopathien kann ausgegangen werden, da Typ-I Kollagen sehr resistent gegen den enzymatischen Abbau ist und nur bestimmte MMPs es bei neutralem pH degradieren können (Brinckerhoff and Matrisian 2002). Einige MMPs sind Elastasen, die auch Typ IV Kollagen zersetzen können (Parks et al. 2004). In mehreren Studien wurde gezeigt, dass MMPs eine zentrale Rolle bei chronischen Lungenerkrankungen des Menschen und des Pferdes spielen. MMPs werden als wichtigste proteolytische Enzyme in der Pathogenese der humanen COPD vermutet (Atkinson et al. 2011, Russell et al. 2002). Erhöhte Level an MMP- 1 und MMP-9 wurden in der BALF von Emphysempatien- 
ten nachgewiesen (Finlay et al. 1997a), diese werden hauptsächlich von Makrophagen freigesetzt (Finlay et al. 1997b).

Auch beim Pferd wurden bereits einige Studien durchgeführt, in denen Metalloproteinasen in BALF Proben zymographisch untersucht wurden. Bei der RAO wurden bei mittel- bis hochgradig erkrankten Pferden erhöhte MMP-2 und MMP-9 Konzentrationen im Vergleich zu gesunden Kontrolltieren gefunden (Koivunen et al. 1997a). Dabei scheint der MMP-9 die größere pathophysiologische Bedeutung zuzukommen (Barton et al. 2013). Beide Metalloproteinasen zeigten eine Korrelation zur Stallstaubkonzentrationen, welcher Schimmelpilzsporen und Endotoxine enthält (Nevalainen et al. 2002, Simonen-Jokinen et al. 2005a und 2005b). Die MMP-9 korrelierte zusätzlich zur Neutrophilie in der BALF und nahm mit sinkendem Neutrophilenanteil unter Therapie ab (Barton et al. 2013). Dieses war für die MMP-2 nicht der Fall, da sie vermutlich eher eine physiologische Rolle im Rahmen des Gewebe-Remodellings spielt (Koivunen et al. 1997a). Raulo et al. (2001a) konnten ebenfalls keine erhöhten MMP-2 und MMP14 Aktivitäten in TBS und BALF bei der RAO nachweisen, wohl jedoch eine Erhöhung der MMP-9. Außerdem wurden bis zu 7-fach erhöhte Aktivitäten von MMP-8 und MMP-13 nachgewiesen (Raulo et al. 2001b), welche aus Makrophagen und Epithelzellen stammen.

Es erscheint wünschenswert, therapeutische Ansätze zu entwikkeln, die die Lunge vor überschießender Aktivität der MMPs schützen, gleichzeitig aber das physiologische Zell-Remodelling zulassen, welches immunologisch für Heilungsprozesse von Bedeutung ist (Elkington und Friedland 2006). Um einen unkontrollierten Turnover der ECM, Inflammation, Zellwachstum und -migration zu vermeiden, muss die Aktivität der Metalloproteinasen genau reguliert werden. Dies kann auf den Ebenen der Transkription, Zymogenaktivierung und der Hemmung durch endogene Inhibitoren erfolgen. Die überschießende Aktivität der Metalloproteinasen konnte in vitro mittels Doxyzyklin inhibiert werden (Koivunen et al. 1997b).
Gewebeinhibitoren der Metalloproteinasen (TIMPs) sind natürliche, endogene MMP-Inhibitoren, die in den MMP-vermittelten Turnover der ECM, das Gewebe-Remodelling und das zelluläre Verhalten eingreifen (Bourboulia und Stetler-Stevenson 2010, Brew und Nagase 2010). Bei der Tuberkulose des Menschen sind neben verschiedenen MMPs auch die TIMP-1 und -2 erhöht (Ugarte-Gil et al. 2013) und nehmen unter erfolgreicher Therapie ab. Bei der humanen COPD wurden lokal in der BALF erhöhte MMP-9 und TIMP-1 Konzentrationen gemessen, im Plasma jedoch erniedrigte Werte (D'Armiento et al. 2013). Bei interstitiellen Lungenerkrankungen mit Kollagenstörungen werden MMP und TIMP Muster als mögliche prognostische Indikatoren und TIMPs als Therapieansatz diskutiert (Oka et al. 2013). Es gibt einige synthetische Inhibitoren, die die pathologischen Effekte der MMPs regulieren können und somit möglicherweise den Heilungsprozess und die Wiederherstellung epithelialer Barrieren verbessern könnten (Bourboulia und Stetler-Stevenson 2010, Brew and Nagase 2010).

\section{Schlussfolgerungen}

Zusammenfassend zeigen die Ergebnisse der hier vorgestellten Studien die Komplexität in der Pathogenese der tiefen Atemwegserkrankungen beim Pferd. Es ist daher nicht einfach, neve therapeutische Ansätze für diese wirtschaftlich bedeutenden Erkrankungen zu finden. Die zahlreichen auch beim Pferd bereits untersuchten lokalen und systemischen Entzündungsmarker könnten jedoch helfen, die Pathogenese dieser Krankheiten besser zu verstehen und auch in subklinischen Fällen eine korrekte Diagnose zu stellen. In weiteren Studien sollte der Verlauf der verschiedenen Entzündungsmarker unter Therapie des Pferdes untersucht werden, um ihre Eignung zur Verlaufskontrolle zu überprüfen und den Erfolg etablierter, aber auch never Therapieansätze besser beurteilen zu können. 